\title{
DAMAGE TO REMAINING TREES BY FOUR SYSTEMS OF MECHANIZED HARVEST IN COMMERCIAL THINNING OF Pinus radiata
}

\author{
DANOS ÀS ÁRVORES REMANESCENTES POR QUATRO SISTEMAS DE COLHEITA \\ MECANIZADA NO DESBASTE COMERCIAL DE Pinus radiata
}

\author{
Eduardo Acuña ${ }^{1}$ Eugenio Sanfuentes ${ }^{2}$ Jorge Cancino $^{1}$ Pablo Mena ${ }^{3}$
}

\begin{abstract}
The effect of four harvesting systems for thinning tasks (harvester-forwarder, chainsaw-skidder, chainsawthree-wheeled loader and chainsaw-yarder) was evaluated on percentage of damaged trees and damage surface. Additionally, the effect of the logging system and the season of the operation (winter and summer) on the incidence of damage and surface of the injuries, and their relationship with tree diameter, was also analyzed. Of the four logging systems studied, those carried out with chainsaw-yarder and harvesterforwarder originated the greater incidence of damage with $34.5 \%$ and $32.2 \%$, respectively, also producing the greatest injuries with 349.7 and $427.2 \mathrm{~cm}^{2}$, respectively, by individual tree. The season in which the operations were conducted is a factor that significantly affected on the increase of the number of trees with some sort of damage, with an average incidence of $27.1 \%$ in winter and $10.1 \%$ in summer. In addition, tree extraction with forwarder and yarder has a high potential for residual stand damage, and the stand structure was not affected by mechanized thinning, because there were damages in all sizes of remaining trees.
\end{abstract}

Keywords: harvesting equipment; stem damage; injuries; harvest season.

\section{RESUMO}

Quatro sistemas de colheita de madeira foram avaliados nas atividades de desbaste de povoamentos de Pinus radiata (harvester-forwarder, motosserra-skidder, motosserra-carregadora de três rodas e motosserrayarder), considerando seu impacto no percentual de árvores e superfície afetada. Adicionalmente, foi analisado o efeito combinado do sistema colheita e estação do ano (verão e inverno), na incidência e área de injúria, e sua relação com o diâmetro das árvores. Entre os sistemas de colheita estudados, aqueles que utilizaram motosserra-yarder e harvester-forwarder tiveram maior incidência de injúria mecânica nas árvores, atingindo $34,5 \%$ e 32,2\%, respectivamente; como também em uma maior área injuriada por árvore com 349.7 e $427.2 \mathrm{~cm}^{2}$, respectivamente. A estação do ano para as operações de colheita foi um fator que aumentou significativamente o número de árvores com algum nível de injúria, variando entre 27,1\% no inverno e $10,1 \%$ no verão. Entretanto, o estudo mostrou também que a extração da árvore com o forwarder e yarder tem um alto potencial de dano residual no povoamento, sendo que sua estrutura não foi afetada pelo desbaste mecanizado, porque foram danificadas árvores em todas as classes de tamanho.

Palavras-chave: equipamento de colheita; dano no tronco; lesões; época de colheita.

\section{INTRODUCTION}

Mechanization of thinning operations in forests is increased worldwide. The reasons for this trend are generally productivity goals or work-related problems, such as security and in some cases to reduce

1 Forest Engineering, Dr., Professor at Departamento Manejo de Bosques y Medio Ambiente, Universidad de Concepción, Victoria 631, Ciudad Universitaria, CP 4030000, Concepción, Chile. edacuna@udec.cl / jcancino@udec. $\mathrm{cl}$

2 Forest Engineering, Dr., Professor at Departamento Silvicultura, Universidad de Concepción, Victoria 631, Ciudad Universitaria, CP 4030000, Concepción, Chile. esanfuen@udec.cl

3 Forest Engineering, MSc., Professor at Departamento Manejo de Bosques y Medio Ambiente, Universidad de Concepción, Victoria 631, Ciudad Universitaria, CP 4030000, Concepción, Chile. pablomena@udec.cl

Recebido para publicação em 7/11/2016 e aceito em 7/07/2017

Ci. Fl., v. 28, n. 3, jul. - set., 2018 
environmental impacts (MARSHALL, 2007). However, the machinery introduced has had some negative effects on its biological results. Damage to the remaining trees as a result of their use is one of the more fundamental elements in the evaluation of the sustainability of thinning (PICARD et al., 2012).

Damage to trees may result in loss of vigor and reduce tree growth (DIMITRI, 1983). Damage to the remaining trees can also reduce the value of the timber due to the volume loss caused by discoloration of the timber or decomposition. Damage and severity of the injuries, time elapsed since the lesion and the species being damaged are directly related with the decay of the trees (SHIGO, 1979). Because of the potential decreased tree vigor and the increase of the probability of attack of insects or diseases, the damage of the remaining trees can cause serious economic losses in terms of the quality of timber in the final harvest (KISER, 2011). Tree damage during the thinning process depends on various factors such as: density and composition of the understory, structure of the stand, density of the cutting, size and maneuverability of the equipment used, season of intervention, topography of the ground and planning level (WHITE; KILE, 1991). The extraction system or harvest system is the factor that produces major damage (FALLOON, 1991; NIKOOY et al., 2010). Some studies that evaluate tree damage by some system of exploitation correspond to Nordlund (1996) in mixed stand of Pinus sylvestris L. and Picea abies L., McNeel and Ballard (1992) in Pseudotsuga menziesii, Heitzman and Grell (2002) in Picea rubens (Sarg.) and Froese and Han (2006), with harvester-forwarder; Yu et al. (2016) with a claw harvester-skidder, Spinelli et al. (2010) with chainsawyarder, and Tavankar et al. (2015) with harvester-forwarder and harvester-yarder, among others.

In Chile, Pinus radiata is the most important specie in the trade of commodities, especially cellulose and lumber. At present, the Pinus radiata plantations are usually established in densities of 8001600 trees ha $\mathrm{a}^{-1}$. The trees are pruned up to 5-6 $\mathrm{m}$ in height in successive stages. The trees are thinned early on to produce knot-free wood, leaving the best trees, to improve the quality and concentrate in them the productive potential of the site. The trees are commercially thinned at 11-15 years of age, depending on site quality; and the rotation length extends between 20-26 years (FUNDACIÓN CHILE, 2005). In the second or third commercial thinning is usual to use the cut to length (CTL) method, in which the tree stems are processed into smaller logs at the harvesting site. The CTL method is generally regarded as a more environmentally friendly, versatile and safe method that provides end products of more consistent and higher quality than others mechanized methods (TUFTS, 1997).

Despite this, there are still few studies concerning the impact of the exploitation system on the remaining trees in thinning activities. Therefore, this study was aimed to: i) compare the effects of damage to the remaining stand of four logging systems, ii) determine if harvesting season (winter and summer) contributes to the damage to the remaining trees, and iii) evaluate the effect of the diameter distribution on the proportion of trees that presented some sort of damage.

\section{MATERIALS AND METHODS}

\section{Study area}

The present study was carried out in six farms established with Pinus radiata, i.e. Colicheu, Primavera Las Rosas, Tapihue, Los Laureles, Los Barros and Lomas Coloradas, Chile. The farms Colicheu, Primavera Las Rosas and Tapihue are located in the Central Valley, have a flat topography and sandy loam soils, with a slope of $2 \%$, and no presence of understory. Colicheu, with a 15 year plantation and a site index of 28 , is located 15 Northeast of Cabrero ( $37^{\circ} 1^{\prime} 26.26^{\prime \prime} \mathrm{S}$ and $72^{\circ} 14^{\prime} 8.89^{\prime \prime} \mathrm{W}$ ). The farm Primavera Las Rosas has two stands of 14 years with site index of 31 and 28.8 and it is located $17 \mathrm{~km}$ Southeast Cabrero ( $37^{\circ} 6^{\prime} 29.40^{\prime \prime} \mathrm{S}$ and $\left.72^{\circ} 14^{\prime} 7.94^{\prime \prime} \mathrm{W}\right)$. Tapihue has a stand of 15 years and a site index of 29.8 , and it is located $14.5 \mathrm{~km}$ Southeast Cabrero ( $37^{\circ} 7^{\prime} 41.35^{\prime \prime} \mathrm{S}$ y $\left.72^{\circ} 23^{\prime} 2.67^{\prime \prime} \mathrm{W}\right)$. The sites have a mean annual rainfall of $1081 \mathrm{~mm}$ and minimum, mean and maximum mean annual temperatures of $6.4^{\circ} \mathrm{C}, 12.9^{\circ} \mathrm{C}$ and $19.3^{\circ} \mathrm{C}$, respectively. Soil belong to Arenales soils series, which is a member of the mixed thermal family of Dystric Xeropsamments (Entisol) (CENTRO DE INVESTIGACIÓN DE RECURSOS NATURALES, $1999)$ derived from andesitic and basaltic sands, deep $(>150 \mathrm{~cm})$ and with surface loamy texture and deep coarse sandy soil texture in depth.

Farms Los Laureles and Los Barros are located in the eastern slope of the Nahuelbuta Mountains, 
have topography composed of mild hills and soils of granitic origin. The first farm is located $19.2 \mathrm{~km}$ West of Nacimiento $\left(37^{\circ} 31^{\prime} 50.94\right.$ " S y $\left.72^{\circ} 53^{\prime} 27.12^{\prime \prime} \mathrm{W}\right)$, the intervened stand has 14 years and a site index of 26.9 and an average slope of $22 \%$, without presence of understory. Los Barros is located $25 \mathrm{~km}$ Southeast of Nacimiento $\left(37^{\circ} 36^{\prime} 11.09^{\prime \prime} \mathrm{S}\right.$ y $\left.72^{\circ} 55^{\prime} 45.82^{\prime \prime} \mathrm{W}\right)$, with 2 stands of 15 and 14 years, site index of 31.7 and 26.3 , and an average slope of $29 \%$ will little understory dominated by blackberry (Rubus ulmifolius). The sites have a mean annual rainfall of $1089 \mathrm{~mm}$ and minimum, mean and maximum mean annual temperatures of $7.1^{\circ} \mathrm{C}, 12.8^{\circ} \mathrm{C}$ and $19.7^{\circ} \mathrm{C}$, respectively. Soil belong to Culenco soils series, which is a member of the mixed thermal family of Typic Argixerolls (Mollisol) (CENTRO DE INVESTIGACIÓN DE RECURSOS NATURALES, 1999). It is an Evolved soil, deep, partially developed from weathered granitic materials. Surface texture is silty clay loam and silty clay loam and loamy texture in depth. It occupies intermediate to high level within the general landscape and presents a moderately undulating topography to hills, with slopes of 8 to $30 \%$. Well drained and moderately slow permeability. Soil highly susceptible to water erosion.

Finally, the farm Lomas Coloradas is located in the western slope of the Nahuelbuta Mountains, has soils of metamorphic origin with a topography of mild slopes, located $11 \mathrm{~km}$ South of Concepción $\left(36^{\circ} 52^{\prime} 45.56^{\prime \prime} \mathrm{S}\right.$ y $\left.73^{\circ} 6^{\prime} 53.09^{\prime \prime} \mathrm{W}\right)$, with two intervened stands of 13 years old, site index of 32.1 and 33.8 , with an average slope of $33 \%$, and an understory with little presence of blackberry and maqui (Aristotelia chilensis). Lomas Coloradas have a mean annual rainfall of $1110 \mathrm{~mm}$ and minimum, mean and maximum mean annual temperatures of $7.2^{\circ} \mathrm{C}, 11.5^{\circ} \mathrm{C}$ and $16.4^{\circ} \mathrm{C}$, respectively. Soil belong to Tomé soils series, which is a member of the mixed isomesic family of Typic Palexerults (Ultisol) (CENTRO DE INVESTIGACIÓN DE RECURSOS NATURALES, 1999). Deep soils, well evolved, loamy clay texture. Rests on ancient marine sediments (claystones) and/or metamorphic rocks of phyllite type. It occupies a position of gently undulating marine terrace, dissected by small ravines. Well-structured soils, good porosity, moderate permeability and good drainage.

\section{Machinery evaluated}

A thinning from below was prescribed at all sites. The thinned trees were processed in two products: i) sawlog with a length of $3.15 \mathrm{~m}$, in diameters of $18 \mathrm{~cm}$ or more, and ii) $3.5 \mathrm{~m} \operatorname{logs}$ for pulp, in diameter of 8 to $16 \mathrm{~cm}$. A total of four harvesting systems were evaluated for 12 days, in working shifts of approximately 8 hours daily. The systems are: i) harvester-forwarder (H-F), with a Timberjack 1270D harvester, equipped with a Timberjack $762 \mathrm{C}$ harvesting and processing head, which performed the activities of felling, pruning and bucking trees, and a Timberjack 1710D forwarder extracting logs, classifying and ordering them on the roadside; ii) chainsaw-skidder (C-S), felling carried out manually by an operator by means of a Stihl 017 chainsaw and logging through a John Deere 540 G3 cable skidder; iii) chainsaw-three wheeled logger (C-TWL), felling performed with a Stihl 017 chainsaw and logging with a Bell 220-A three-wheeled logger; and iv) chainsaw-yarder (C-Y), felling performed with a Stihl 017 chainsaw and logging on Urus I 300 yarder.

Operators of Timberjack 1270D harvester, Timberkack 1710D forwarder, John Deere 540 G3 cable skidder, Bell 220-A three-wheeled logger and Urus I 300 yarder, had more than 5 year experience in working with studied machine. The Stihl 017 chainsaw operator had more than 6 year experience. The same operators worked in winter and summer tasks. By regulation of forestry companies in Chile, all forest workers, including forestry machinery operators, must be certified by Corporación Chilena de la Madera (CORMA).

\section{Field sampling}

Immediately after the thinning, the damage to the remaining trees was evaluated in the ten cases by means of a systematic sampling (HAN; KELLOGG, 2000a; HARTSOUGH, 2003; TAVANKAR et al., 2015). In each of the intervened sites, three sampling units per each combination of logging system and season of thinning were established. The record was carried out between January and April for the summer thinnings and between June and July for the winter thinnings. Diameter at breast height (DBH) and total heights were recorded to all trees of the sampling unit (Table 1). Damage to remaining trees was evaluated 
according to the method proposed by Hartsough (2003), which considers different degrees or levels of damage. These are: 1. Tree cut or knocked over, 2. Broken top: height to break, 3. Root damage: area of exposed cambium, 4 . Bark removal up to $30 \mathrm{~cm}$ above ground: area of exposed cambium, 5 . Bark removal after $30 \mathrm{~cm}$ above the ground: area of exposed cambium, and 6. Crown damage: percent of crown removed. Both DBH and height were measured to all remaining undamaged trees. For injuries in the stem located above 2 meters, length and width were measured with a Trimble LaserAce 1000 hypsometer (Trimble Navigation Limited, Sunnyvale, California).

Sampling units were generated according to the position of the logging lines (BUSTOS et al., 2010). Logging lines were separated approximately $30 \mathrm{~m}$ from each other. Thus, between each line a sampling unit located parallel thereto of $100 \mathrm{~m}$ long and $10 \mathrm{~m}$ wide was established.

TABLE 1: Equipment used and inventory of each stand before and after thinning operations.

TABELA 1: Equipamentos utilizados e inventário de cada povoamento antes e depois das operações de desbaste.

\begin{tabular}{|c|c|c|c|c|c|c|c|c|c|c|c|c|c|c|c|c|}
\hline \multirow[t]{2}{*}{ Farm } & \multirow[t]{2}{*}{ System } & \multirow[t]{2}{*}{ Season } & \multirow[t]{2}{*}{ Pruning } & \multirow[t]{2}{*}{$\begin{array}{l}\text { Area } \\
\text { (ha) }\end{array}$} & \multirow[t]{2}{*}{$\begin{array}{l}\text { Site index } \\
\text { (m) }\end{array}$} & \multirow[t]{2}{*}{$\begin{array}{l}\text { hinning age } \\
\text { (year) }\end{array}$} & \multicolumn{3}{|c|}{$\begin{array}{l}\text { Planting density } \\
\quad\left(\text { tree ha }^{-1}\right)\end{array}$} & \multicolumn{4}{|c|}{$\begin{array}{l}\text { Mean height Mean DBH } \\
\begin{array}{cc}(\mathrm{m}) & (\mathrm{cm})\end{array}\end{array}$} & \multirow{2}{*}{$\begin{array}{l}\text { Mean } \\
\text { tree per } \\
-\quad \text { plot }\end{array}$} & \multirow{2}{*}{$\begin{array}{c}\text { Mean } \\
\text { volume } \\
\text { per tree } \\
\left(\mathrm{m}^{3}\right)\end{array}$} & \multirow{2}{*}{$\begin{array}{l}\text { Remova } \\
\text { intensity } \\
\left(\mathrm{m}^{3} \mathrm{~h}^{-1}\right)\end{array}$} \\
\hline & & & & & & & Initial & BT & AT & BT & AT & $\mathrm{BT}$ & $\mathrm{AT}$ & & & \\
\hline Los Laureles & $\mathrm{H}-\mathrm{F}$ & W-S & 2 & 28.9 & 26.9 & 14 & 1,35 & 833 & 531 & 14.5 & 19.8 & 17.1 & 24.1 & 21.2 & 0.38 & 21.4 \\
\hline $\begin{array}{l}\text { Lomas } \\
\text { Coloradas }\end{array}$ & C-S & W & 5 & 47.3 & 33.8 & 13 & 1,283 & 658 & 408 & 15.1 & 21.8 & 19.4 & 25.9 & 22.9 & 0.48 & 20.7 \\
\hline Los Barros & C-S & $\mathrm{S}$ & 4 & 81.2 & 31.7 & 15 & 1,355 & 743 & 447 & 12.3 & 23.5 & 14.3 & 22.3 & 19.99 & 0.26 & 18.0 \\
\hline $\begin{array}{l}\text { Lomas } \\
\text { Coloradas }\end{array}$ & $\mathrm{C}-\mathrm{Y}$ & W & 4 & 32.6 & 32.1 & 13 & 1,353 & 573 & 373 & 11.6 & 20.5 & 17.2 & 25.8 & 19.7 & 0.39 & 20.2 \\
\hline Los Barros & $\mathrm{C}-\mathrm{Y}$ & $\mathrm{S}$ & 2 & 19.8 & 26.3 & 14 & 1,111 & 1 & 635 & 14.7 & 20.3 & 14.8 & 19.0 & 27.8 & 0.38 & 20.0 \\
\hline Primavera & C-TWL & W & 2 & 14.1 & 28.8 & 14 & 1,258 & 1,2 & 550 & 15.5 & 19.9 & 17.1 & 22.0 & 23.1 & 0.37 & 16.2 \\
\hline Primavera & C-TWL & $\mathrm{S}$ & 4 & 38.9 & 31.0 & 14 & 863 & 717 & 357 & 13.1 & 21.0 & 17.3 & 23.7 & 17.3 & 0.28 & 11.3 \\
\hline Colicheu & C-TWL & W & 3 & 26.7 & 28.0 & 15 & 1,287 & 638 & 363 & 14.5 & 19.8 & 19.3 & 23.6 & 16.6 & 0.32 & 12.9 \\
\hline Tapihue & C-TWL & $\mathrm{S}$ & 3 & 18.4 & 29.8 & 15 & 1,556 & 992 & 496 & 16.5 & 20.1 & 18.6 & 21.5 & 21.91 & 0.31 & 12.7 \\
\hline
\end{tabular}

Where: BT was before thinning and AT was after thinning. Site index to Pinus radiata plantations in Chile is the mean height of dominant and codominant trees at the age of 20 years.

\section{Data analysis}

An analysis of variance was conducted, taking the logging system as the independent variable. Variables analyzed in the study were: damage surface, percentage of damaged trees, percentage of trees with damage in low part of the stem and above $30 \mathrm{~cm}$ height in the stem, and percentage of trees with damage in roots and crown. Along with this, the effect of the machinery and the season on the surface of the damage and the percentage of trees that presented some type of damage was analyzed. This analysis was conducted with a completely random design with $2 \times 2$ factorial arrangements with three repetitions, where the logging system and the season form the independent variables of the model. The effect of the treatments was analyzed by means of the Tukey's multiple comparison tests $(P<0.05)$. In order to predict the probability of some sort of damage to the remaining tree as a result of the thinning, a logistic regression model was 
applied using the diameter of the tree as explanatory variable (SURAKKA et al., 2011; TATSUMI et al., 2014). The model is expressed according to equation [1].

$$
P=\frac{1}{1+e^{-\left(b_{0}+b_{1} x_{i}\right)}}
$$

Where, $P$ corresponds to the probability that a tree of a diametric class $x_{i}$ presents evidence of some type of injury, $e$ is the natural antilogarithm, $b_{0}$ and $b_{1}$ correspond to the parameters of the linear model that models the probability of the binomial process that a tree has or no evidence of damage ( 1 or 0 , respectively). The significance of the parameter $b_{1}$ indicates whether the diametric class is a factor that significantly affects the incidence of damage to the trees.

Both the analysis of variance and the logistic regression were performed with the options PROC GLM and LOGISTIC of the software SAS Version 9.2 (SAS INSTITUTE, 2009).

\section{RESULTS}

Systems harvester-forwarder and chainsaw-yarder produced greater impact on the surface of the damage, number of remaining trees, crown damage and damage under $30 \mathrm{~cm}$. Damage to stems above 30 $\mathrm{cm}$ were greater in both systems, being greater than that produced by chainsaw-yarder. Root damage was produced only by chainsaw-skidder system, with $2.4 \%$ of damage (Table 2 ).

TABLE 2: Damaged surface $\left(\mathrm{cm}^{2}\right)$, damaged trees and type expressed as the average percentage of trees affected by the exploitation system.

TABELA 2: Superfície danificada $\left(\mathrm{cm}^{2}\right)$, árvores danificadas e tipo de injúria expresso como a porcentagem média de árvores afetadas pelo sistema de colheita.

\begin{tabular}{|c|c|c|c|c|c|c|c|c|c|}
\hline \multirow{2}{*}{ System } & \multirow{2}{*}{ Season } & \multirow{2}{*}{$\begin{array}{c}\text { Damaged } \\
\text { surface } \\
\left(\mathrm{cm}^{2}\right)\end{array}$} & \multirow{2}{*}{$\begin{array}{c}\text { Damaged } \\
\text { trees } \\
(\%)\end{array}$} & \multicolumn{6}{|c|}{ Type of damage (\%) } \\
\hline & & & & Under $30^{1}$ & Above 30 & Root & Knocked & $\begin{array}{c}\text { Crow } \\
\text { damage }\end{array}$ & $\begin{array}{c}\text { Crown damage } \\
>50 \%\end{array}$ \\
\hline Harvester-forwarder & Winter & 454.0 & 37.7 & 9.1 & 26.0 & 0.0 & 0.0 & 3.9 & 0.0 \\
\hline Harvester-forwarder & Summer & 400.3 & 21.6 & 5.4 & 15.3 & 0.0 & 0.0 & 2.6 & 0.0 \\
\hline Chainsaw-skidder & Winter & 0.0 & 9.5 & 0.0 & 0.0 & 0.0 & 0.0 & 9.5 & 0.0 \\
\hline Chainsaw-skidder & Summer & 227.5 & 3.0 & 2.0 & 2.0 & 0.0 & 0.0 & 2.5 & 0.0 \\
\hline Chainsaw-yarder & Winter & 375.8 & 42.1 & 3.3 & 38.0 & 0.0 & 2.4 & 2.4 & 0.0 \\
\hline Chainsaw-yarder & Summer & 323.6 & 23.5 & 8.2 & 9.1 & 7.4 & 0.0 & 6.8 & 0.0 \\
\hline $\begin{array}{l}\text { Chainsaw-three } \\
\text { wheeled logger }\end{array}$ & Winter & 200.2 & 13.4 & 0.0 & 13.4 & 0.0 & 0.0 & 0.0 & 0.0 \\
\hline $\begin{array}{l}\text { Chainsaw-three } \\
\text { wheeled logger }\end{array}$ & Summer & 48.4 & 5.8 & 1.1 & 4.7 & 1.1 & 0.0 & 0.0 & 1.2 \\
\hline
\end{tabular}

${ }^{1}$ The same tree can have damage under and above $30 \mathrm{~cm}$.

The analysis of variance shows that the logging system had significant effects on both damaged surface and the percentage of damaged trees $(P<0.0001)$. On the other hand, the season in which thinning was performed only had effects on the percentage of the damaged trees. However, there was no significant interaction between logging system and the season of exploitation on the studied variables (Table 3 ). 
TABLE 3: Results obtained in the analysis of variance.

TABELA 3: Resultados obtidos na análise de variância.

\begin{tabular}{lcc}
\hline \multirow{2}{*}{ Analysis of variance } & \multicolumn{2}{c}{$P$ values } \\
\cline { 2 - 3 } & $\begin{array}{c}\text { Damaged surface } \\
\left(\mathrm{cm}^{2}\right)\end{array}$ & $\begin{array}{c}\text { Damaged trees } \\
(\%)\end{array}$ \\
\hline System & 0.0000 & 0.0000 \\
Season & 0.5634 & 0.0297 \\
System $\times$ Season & 0.6787 & 0.6705 \\
\hline
\end{tabular}

The effect of the treatments through the Tukey's test is presented in Figure 1. Thus, for the surface of damage in the stems, performing a thinning with harvester-forwarder in winter produced the highest damage, but no damage was observed in winter with the chainsaw-yarder system. On the other hand, the number of damaged trees was greater when the thinning was performed with chainsaw-yarder in winter season. It can be noted that by performing the exploitation in winter either with chainsaw-yarder or chainsaw-skidder an increased number of trees affected by some sort of damage was always obtained.

The ANOVA detected that the systems harvester- forwarder and chainsaw-yarder cause more damage and larger injuries than the chainsaw-skidder or chainsaw-three wheeled systems, this can be explained due to logging often caused scarring at the base of the trees, by logs skidding and tire or tracks of forwarders. The ANOVA detected a random effect of Season, which was significant only in Damaged Surface, this greater damage of trees in winter season is mainly due to the soil conditions, when operation of felling trees was more difficult to control.
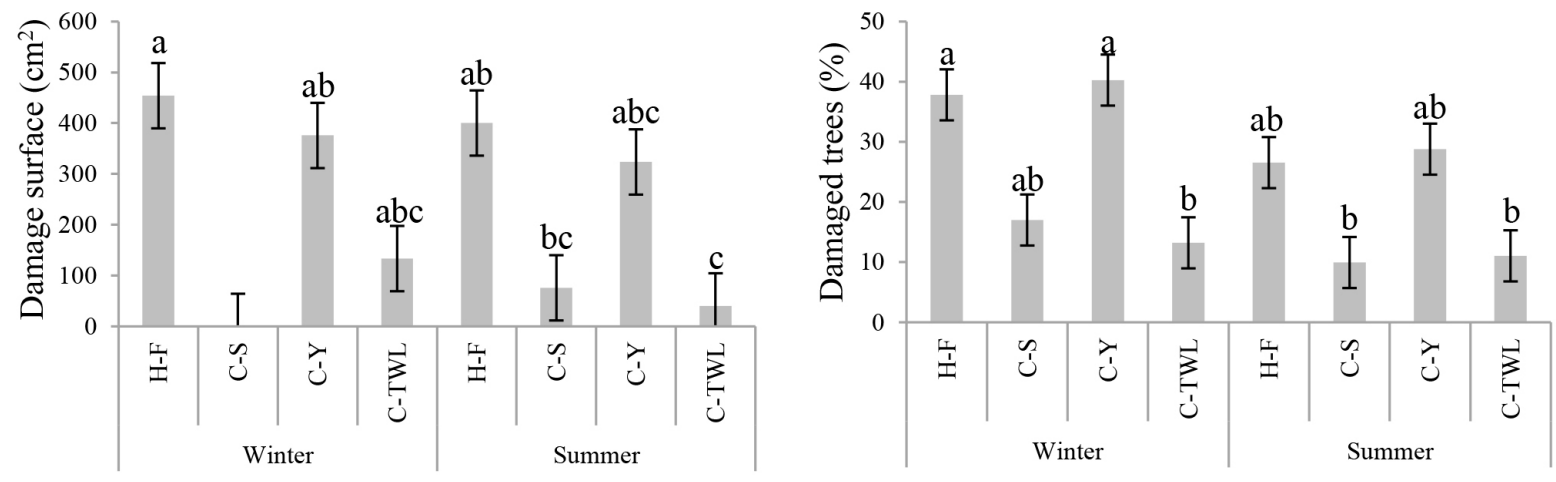

FIGURE 1: Effect of the thinnings system and the season on the surface damage and the percentage of damaged trees. Letters indicate groups of means generated according to Tukey along with confidence intervals $(\alpha$ $=0.05$ ).

FIGURA 1: Efeito do sistema de desbaste e da estação sobre os danos superficiais e a porcentagem de árvores danificados. As letras indicam grupos de média gerados de acordo com Tukey juntamente com intervalos de confiança $(\alpha=0,05)$.

The highest percentage of trees with damage in their crown was produced with the chainsawskidder system, followed by harvester-forwarder and chainsaw-yarder systems. Being the first system significantly different from the others $(P=0.0035)$. This, in statistical terms implies that between three thinning methods, the average percentage of trees that recorded crown damage were the same. Among the logging systems that produce damages below $30 \mathrm{~cm}$ in the stems there were highly significant differences $(P<0.0001)$. Exploitation by harvester-forwarder and chainsaw-yarder produced the greatest incidence of damage, being the damage product of the operations with chainsaw-skidder and chainsaw-three-wheeled 
logger the lowest and statistically different from the damage produced in the processes with harvesterforwarder and chainsaw-yarder. Damage above $30 \mathrm{~cm}$ was produced mainly by performing the process with chainsaw-yarder and harvester-forwarder, being its difference statistically significant with the operations of chainsaw-skidder and chainsaw-three-wheeled logger.

The average surface of the injuries caused by chainsaw-three-wheeled logger and chainsaw-yarder was significantly different to the size of the damage in the operations with chainsaw-three-wheeled logger and chainsaw-skidder (Figure 2). Thus, the largest injuries (above $300 \mathrm{~cm}^{2}$ ) were generated with harvesterforwarder and chainsaw-yarder, and the smallest injuries were caused with chainsaw-three-wheeled logger and chainsaw-skidder, which presented significant differences between them $(P<0.0001)$.
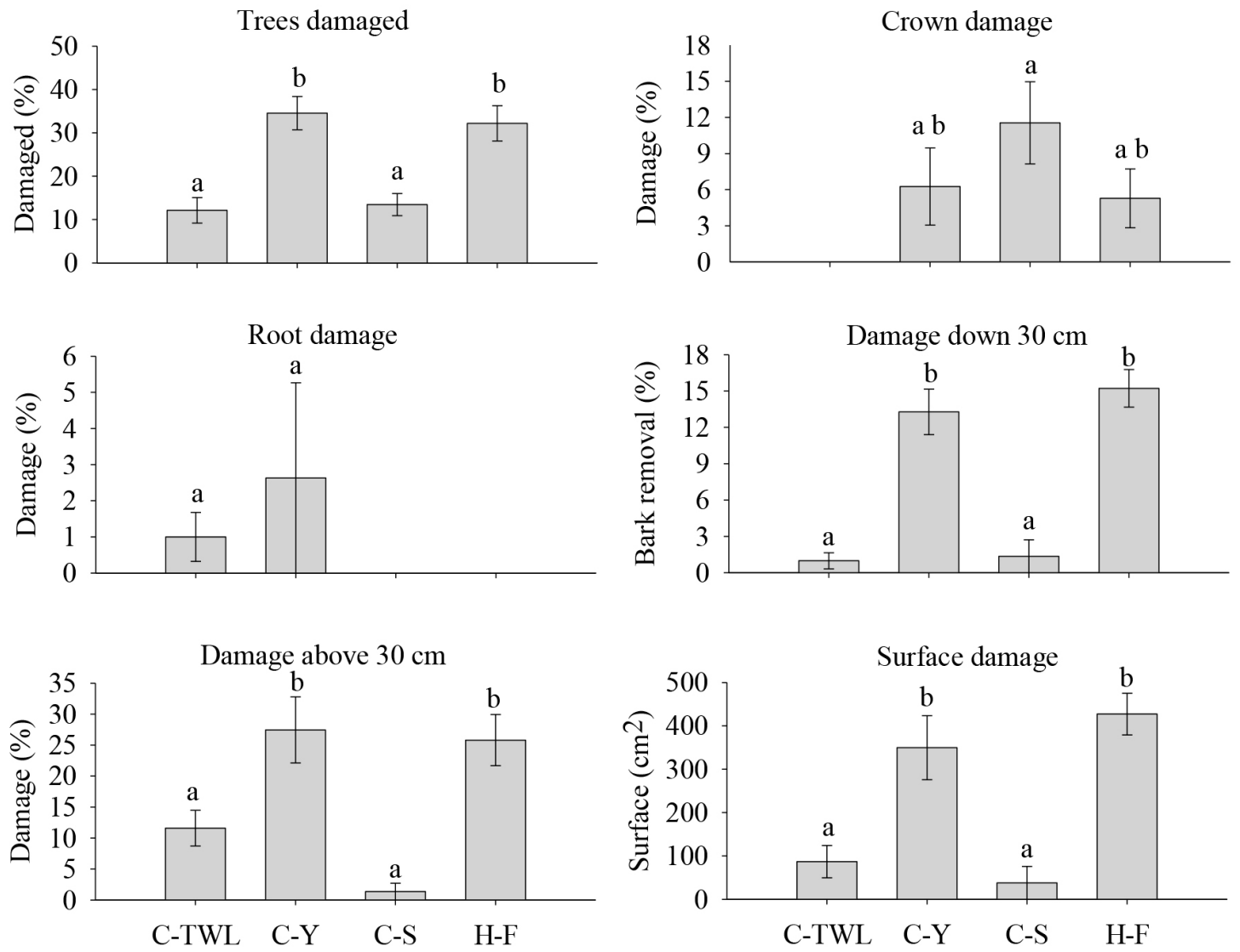

FIGURE 2: Effect of the exploitation system in thinning on different types of damage in remaining trees. Letters indicate groups of means generated according to Tukey along with confidence intervals.

FIGURA 2: Efeito do sistema de exploração no desbaste sobre diferentes tipos de danos nas árvores remanescentes. As letras indicam grupos de média gerados de acordo com a Tukey, juntamente com os intervalos de confiança.

Finally, through logistic regression it was determined that the proportion of incidence of damage as a product of the exploitation with harvester-forwarder was significantly explained by the diametric class. This can be explained by the significance of the parameter $b_{1}$ associated to the diametric class in the analysis of logistic regression in the activity performed with harvester-forwarder and with the significance of the ratio of maximum likelihood ( $P=0.0168$ y $P=0.0149$, respectively) (Table 4). 
TABLE 4: Results obtained in the logistic probability model of occurrence of damage.

TABELA 4: Resultados obtidos no modelo de probabilidade logística de ocorrência de dano.

\begin{tabular}{|c|c|c|c|c|c|c|c|}
\hline Machinery & $b_{0}$ & & $b_{1}$ & & $A I C$ & $R M I$ & \\
\hline $\begin{array}{c}\text { Chainsaw- } \\
\text { three } \\
\text { wheeled } \\
\text { logger }\end{array}$ & $-4.8097(0.0934)$ & ns & $0.0215(0.8543)$ & ns & 35.804 & 0.8548 & $\mathrm{~ns}$ \\
\hline $\begin{array}{c}\text { Chainsaw } \\
\text {-yarder }\end{array}$ & $-1.3035(0.0101)$ & $*$ & $0.0214(0.3013)$ & ns & 465.354 & 0.2975 & ns \\
\hline $\begin{array}{l}\text { Chainsaw } \\
\text {-skidder }\end{array}$ & $-1.6838(0.0125)$ & $*$ & $-0.0297(0.2922)$ & ns & 352.931 & 0.2928 & ns \\
\hline $\begin{array}{l}\text { Harvester- } \\
\text { forwarder }\end{array}$ & $0.7991(0.2500)$ & ns & $-0.0657(0.0168)$ & $*$ & 299.669 & 0.0149 & * \\
\hline Average & $-1.4795(0.0001)$ & $*$ & $-0.0049(0.7109)$ & ns & 1.317 .974 & 0.7110 & ns \\
\hline
\end{tabular}

Where: $b_{0}$ y $b_{1}$ are the parameters in the logistic probability model, $A I C$ Akaike information criterion, $R M V$ is the probability of the reason of maximum likelihood of the model significance under $H_{0}$ de non-significance), * denotes the significance of the parameter $(P<0.05)$ and ns la non-significance of the parameter $(P \geq 0.05)$.

\section{DISCUSSION}

Results indicate that the mechanized thinning operation can cause significant damages to the remaining stand. However, the logging system used in the thinning operations may reflect the amount of damage to the remaining stand (FILIP; SCHMITT, 1990). This damage could have been avoided by means of the application of the procedures of more careful forest exploitation and the application of low impact harvesting systems. The percentage of damaged trees along with the surface of the damage increases by performing thinning operations with logging configurations of harvester-forwarder and chainsaw-yarder. These findings are consistent with those found by Lamson et al. (1984). On the other hand, Wang et al. (2004) state that the proportion of trees damaged by effect of logging methods with skidder is lower than those performed with other mechanized methods. Spinelli et al. (2010) and Tavankar et al. (2013) found $14.9 \%$ and $16.3 \%$ of damage to remaining trees product of the logging of cable-skidder, values slightly higher than those found in this study.

Of the four types of damage analyzed in this study, the highest percentage of incidence occurs above $30 \mathrm{~cm}$. These results are similar to those found by Sirén (2000) in stands of first and second thinning of Picea abies with harvester-forwarder with $92.4 \%$; by Han and Kellogg (2000a) in stands of Pseudotsuga menziesii of 30 to 50 years of age, with $29.4 \%$ and an average height of $1.6 \mathrm{~m}$ (5.3 feet) (HAN; KELLOGG, $2000 \mathrm{~b}$ ), of $12.3 \%$ in Pinus radiata at heights not exceeding $1.5 \mathrm{~m}$ by Lineros, Espinosa and Jiménez (2003), and those recorded by Bustos et al. (2010) at an average height of $1.0 \mathrm{~m}$ for forwarder and skidder in mixed forest with $73 \%$ and 79\%, respectively. On the contrary, Lineros, Espinosa and Acuña (2003) in a study with harvester-forwarder found that the injuries are located preferably in the stump and the first $50 \mathrm{~cm}$ above the ground in Pinus radiata trees.

Vasiliauskas (2001) found that the variation in the frequency of injuries can be attributed to several factors. Among them, the season in which the injury was produced can be mentioned, despite the fact that the resistance of the bark is 1.5 times higher at the end of autumn than in spring (WÄSTERLUND, 1988). In the present study it was found that the frequency of damage is statistically different between seasons in which the thinning is performed; in winter there is greater frequency of damages than in summer, with $27.1 \%$ and $19.1 \%$ respectively. Despite that most of the contemporary studies compare the frequency of damage within the same season; e.g (SPINELLI et al., 2010) and Han and Kellogg (2000b) found differences -although 
non-significant- in the frequencies of damage for winter and summer seasons; for thinning with yarder of $37.3 \%$ and $20,2 \%$, with harvester-forwarder of $34.2 \%$ and $31.9 \%$, and with skidder of $26.9 \%$ and $25.4 \%$, for winter and summer seasons, respectively.

The size of trees is not a factor that affects the incidence of damage, because the higher frequency of damaged trees is grouped in the center of the diametric distribution. This observation is consistent with that proposed by Nichols et al. (1994) who stated that apparently the size of the trees (DBH) is not a significant variable to predict the incidence of damage.

Different logging systems cause different types of residual tree damage. For example, tractor extraction often caused scarring at the butt log, by log skidding and tire or tracks of skidders and forwarders. When winching logs, the skidder often hits trees when repositioning to avoid hang-ups due to a stump or other trees. With chainsaw, when a large tree is falling, heavy bole or broken large branches scratch the bark and remove the branches of residual trees. Sometimes, tops of small trees are broken when felling large trees. With a single grip harvester, a large tree often requires the machine to be off the trails due to handling limitations with large diameter trees, resulting in a greater chance of creating damage to residual trees by the machine body and felling head.

\section{CONCLUSIONS}

The study showed that thinning logging operations carried out during winter season cause higher damage on residual trees than carried out in summer. In any season, our results showed that tree logging with harvester-forwarder have the highest damaged surface. The records of this study indicated also that tree extraction with forwarder and yarder has a higher potential for residual stand damage. The stand structure was not affected by mechanized thinning, because there were damages in all sizes of remaining trees.

\section{ACKNOWLEDGMENTS}

This study was financed by the Vice Presidency of Research and Development of the Universidad de Concepción, DIUC N²04.141.010-1.0

\section{REFERENCES}

BUSTOS, O. et al. A comparison of residual stand damage along yarding trails in a group selection harvest using four different yarding methods. Northern Journal of Applied Forestry, Bethesda, v. 27, n. 2, p. 56$61,2010$.

CENTRO DE INVESTIGACIÓN DE RECURSOS NATURALES (Chile). Estudio Agrológico VIII Región. Descripciones de Suelos, Materiales y Símbolos. Publicación No 121. Santiago: CIREN, 1999. 2 t. DIMITRI, L. Wound decay following tree injury in forestry: establishment, significance and possibilities of its prevention. Forstwissenschaftliches Centralblatt, Weinheim, v. 102, p. 68-79, 1983.

FALLOON, J. Minister gives views on mechanized harvesting. New Zealand Journal of Forestry, Wellington, v. 36, n. 2, p. 10-11, 1991.

FILIP, G. M.; SCHMITT, C. L. Rx for abies: silvicultural options for diseased firs in Oregon and Washington. Portland: Pacific Northwest Research Station; USDA Forest Service, 1990. 34 p.

FROESE, K.; HAN, H.-S. Residual stand damage from cut-to-length thinning of a mixed conifer stand in Northern Idaho. Western Journal of Applied Forestry, Bethesda, v. 21, n. 3, p. 142-148, 2006.

FUNDACIÓN CHILE. Tablas auxiliares de producción. Simulador de árbol individual para pino radiata (Pinus radiata D. Don): arquitectura de copa y calidad de madera. Proyecto Fondef D01/1021. Concepción: Fundación Chile, 2005. 100 p.

HAN, H.-S.; KELLOGG, L. D. A comparison of sampling methods for measuring residual stand from commercial thinning. International Journal of Forest Engineering, Peachtree Corners, v. 11, n. 1, p. 6371, 2000a.

HAN, H.-S.; KELLOGG, L. D. A. Damage characteristics in young Douglas-fir stands from commercial thinning with four timber harvesting systems. Western Journal of Applied Forestry, Bethesda, v. 15, n. 
1, p. 27-33, 2000b.

HARTSOUGH, B. Economics of harvesting to maintain high structural diversity and resulting damage to residual trees. Western Journal of Applied Forestry, Bethesda, v. 18, n. 2, p. 133-142, 2003.

HEITZMAN, E.; GRELL, A. G. Residual tree damage along forwarder trails from cut-to-length thinning in Maine Spruce stands. Northern Journal of Applied Forestry, Bethesda, v. 19, n. 4, p. 161-167, 2002. KISER, J. Histochemical and geometric alterations of sapwood in coastal Douglas-fir following mechanical damage during commercial thinning. Silva Fennica, Vantaa, v. 45, n. 4, p. 729-741, 2011.

LAMSON, N. et al. Residual stocking not seriously reduced damage from thinning of West Virginia cherrymaple stands. In: RESEARCH paper NE-541, 1984. Broomall: Northeastern Forest Experiment Station; USDA Forest Service, 1984. p. 7.

LINEROS, M.; ESPINOSA, M.; ACUÑA, E. Daños en raleo por volteo y extracción animal en Eucalyptus regnans. In: CONGRESO FORESTAL MUNDIAL, 12., 2003, Québec. Anais... [s. 1.: s. n.], 2003. p. 753759.

LINEROS, M.; ESPINOSA, M.; JIMENEZ, A. Daño a los árboles remanentes por sistema harvesterforwarder en raleo comercial de Pinus radiata D. Don. Bosque, Valdivia, v. 24, n. 1, p. 87-93, 2003.

MARSHALL, H. Log merchandizing model used in mechanical harvesting. In: WEINTRAUB, A. et al (Ed.). Handbook of operations research in natural resources. 1st ed. New York: Springer, 2007. p. 379389.

MCNEEL, J. F.; BALLARD, T. M. Analysis of site stand impacts from thinning with a harvester - forwarder system. International Journal of Forest Engineering, Peachtree Corners, v. 4, n. 1, p. 23-29, 1992.

NICHOLS, M. T. et al. The impact of two harvesting systems on residual stems in a partially cut stand of northern hardwoods. Canadian Journal of Forest Research, Ottawa, v. 24, n. 2, p. 350-357, 1994.

NIKOOY, M. et al. Residual trees injury assessment after selective cutting in broadleaf forest in Shafaroud. Caspian Journal of Environmental Science, Guilan, v. 8, n. 2, p. 173-179, 2010.

NORDLUND, S. Logging technology and methods: trends in large-scale forestry. Uppsala: The Forestry Research Institute of Sweden, 1996. 4 p.

PICARD, N. et al. Estimating damage from selective logging and implications for tropical forest management. Canadian Journal of Forest Research, Ottawa, v. 42, n. 3, p. 605-613, 2012.

SAS INSTITUTE. SAS/STAT ${ }^{\circledR} 9.2$ User's Guide. 2 nd ed. Cary: SAS Institute, 2009. 7886 p.

SHIGO, A. L. Tree decay an expanded concept. Washington: USDA Forest Service, 1979. 73 p.

SIRÉN, M. Silvicultural result of one-grip harvester operation. International Journal of Forest Engineering, Peachtree Corners, v. 12, n. 1, p. 29-38, 2000.

SPINELLI, R. et al. Benchmarking the impact of traditional small-scale logging systems used in Mediterranean forestry. Forest Ecology and Management, Amsterdam, v. 260, n. 11, p. 1997-2001, 2010. SURAKKA, H. et al. Damage to saplings in mechanized selection cutting in uneven-aged Norway spruce stands. Scandinavian Journal of Forest Research, Abingdon, v. 26, n. 3, p. 232-244, 2011.

TATSUMI, S. et al. Individual-level analysis of damage to residual trees after single-tree selection harvesting in northern Japanese mixedwood stands. Journal of Forest Research, Tokyo, v. 19, n. 4, p. 369-378, 2014. TAVANKAR, F. et al. Affective factors on residual tree damage during selection cutting and cable-skidder logging in the Caspian forests, Northern Iran. Ecological Engineering, Amsterdam, v. 83, p. 505-512, 2015.

TAVANKAR, F. et al. Felling and skidding damage to residual trees following selection cutting in Caspian forests of Iran. Journal of Forest Science, Praha, v. 59, n. 5, p. 196-203, 2013.

TUFTS, R. A. Productivity and cost of the Ponsse 15-series, cut-to-length harvesting system in southern pine plantations. Forest Products Journal, Peachtree Corners, v. 47, n. 10, p. 39-46, 1997.

VASILIAUSKAS, R. Damage to trees due to forestry operations and its pathological significance in temperate forests: a literature review. Forestry, Oxford, v. 74, n. 4, p. 319-336, 2001.

WANG, J. et al. Log damage and value loss associated with two ground-based harvesting systems in Central Appalachia. International Journal of Forest Engineering, Peachtree Corners, v. 15, n. 1, p. 61-69, 2004. WÄSTERLUND, I. Damages and growth effects after selective mechanical cleaning. Scandinavian Journal of Forest Research, Abingdon, v. 3, n. 1-4, p. 259-272, 1988.

WHITE, D. A.; KILE, G. A. Thinning damage and defect in regrowth eucalypts. In: The young eucalypt 
report - some management options for Australia's regrowth forests, 1991, Canberra: CSIRO Publications, 1991. p. 152-177.

YU, A. et al. Application of a small-scale equipment system for biomass harvesting. Small-scale Forestry, Dordrecht, p. 1-14, 2016. 